substantiated the suitability of fitted response models and satisfactorily predicted the variation in processing parameters. The optimum process conditions for preparation of novel aonla candy were SSC $60^{\circ} \mathrm{B}$, TD $30 \mathrm{~min}$ and DT $70^{\circ} \mathrm{C}$. The study confirms the feasibility of development of this innovative product with a greater nutritive value, which also may attract more attention in the market.

1. Singh, I. S. and Pathak, R. K., Evaluation of amla varieties for processing. Acta Hortic., 1987, 208, 173-177.

2. Mahawar, M. K., Jalgaonkar, K. R., Kadam, D. M. and Chavan, P., Entrepreneurial skill development through aonla processing in Punjab, India. Food Sci. Nutr. Stud., 2017, 1(1), 23-30.

3. Singh, S., Singh, A. K. and Joshi, H. K., Standardization of maturity indices in Indian gooseberry (Emblica officinalis G.) under semi-arid conditions of Gujarat. Indian J. Agric. Sci., 2006, 76, 591-595.

4. Anon., Department of Agriculture and Co-operation, Government of India, 2017; www.indiastat.com (accessed on 20 August 2019).

5. Kumari, P. and Khatkar, B. S., Physico-chemical properties and nutritional composition of aonla (Emblica officinalis G.) varieties. Int. Food Res. J., 2015, 22(6), 2358-2363.

6. Tewari, R., Kumar, V. and Sharma, H. K., Physical and chemical characteristics of different cultivars of Indian gooseberry (Emblica officinalis G.). J. Food Sci. Technol., 2019, 56(3), 1641-1648.

7. Gopalan, C., Ramasastri, B. V. and Balasubramaninan, S. C., Nutritive value of Indian foods. National Institute of Nutrition, ICMR, Hyderabad, 1995, pp. 45-94.

8. Tandon, D. K., Yadav, R. C., Sood, S., Kumar, S. and Dikshit, A., Effect of blanching and lye peeling on the quality of aonla candy. Indian Food Packer, 2003, 57(6), 147-152.

9. Gil, M. I., Tomas-Berberan, A., Hess-Pierce, B., Holcroft, D. M. and Kader, A. A., Antioxidant activity of pomegranate juice and its relationship with phenolic composition and processing. $J$. Agric. Food Chem., 2000, 48, 4581-4589.

10. AOAC, Official method of analysis of the Association of Official Analytical Chemists, Washington, DC, USA, 1990, 15th edn.

11. Ranganna, S., Handbook of Analysis and Quality Control of Fruits and Vegetable Products, Tata McGraw-Hill, New Delhi, 1986.

12. Bibwe, B., Mishra, I. M., Kar, A., Samuel, D. V. K. and Iquebal, M. A., Optimization of oil loading and starch-protein ratio for encapsulation of flaxseed oil using response surface methodology. J. Agric. Eng., 2019, 56(2), 80-90.

13. Mahawar, M. K., Jalgaonkar, K., Bibwe, B., Kulkarni, T., Bhushan, B. and Meena, V. S., Optimization of mixed aonlaguava fruit bar using response surface methodology. Nutr. Food Sci., 2018, 48(4), 621-630.

14. Ingle, M., Patil, J. and Nawkar, R., Nutritional evaluation of sugar free aonla candy. Asian J. Dairy Food Res., 2016, 35(4), 323-326.

15. Vishen, G. S., Pathak, S., Mishra, K. K., Shukla, A. K. and Singh, N. P., Studies on changes during storage of flavored aonla (Emblica officinalis G.) candy cv. Chakaiya in different packaging containers. J. Pharmacogn. Phytochem., 2017, 6(6), 2273-2277.

16. Dwivedi, S. K. and Pandey, A., Development of protocol for preparation and preservation of ginger flavored aonla candy for nutritional and biochemical evaluation. Pharma Innov. J., 2017, 6(11), 78-83.

Received 10 August 2018; revised accepted 5 September 2019

doi: $10.18520 / \mathrm{cs} / \mathrm{v} 118 / \mathrm{i} 1 / 114-118$

\section{Potential application of yellow gypsum from LD slag as a soil conditioner}

\author{
Shrenivas Ashrit ${ }^{1, *}$, Ravikrishna V. Chatti ${ }^{1}$, \\ S. Sarkar ${ }^{1}$, R. Venugopal $^{2}$ and G. Udayabhanu ${ }^{3}$ \\ ${ }^{1}$ R\&D Department, Tata Steel Limited, Jamshedpur 831 007, India \\ ${ }^{2}$ Department of Fuel, Minerals and Metallurgical Engineering, and \\ ${ }^{3}$ Applied Chemistry Department, Indian Institute of Technology \\ (Indian School of Mines), Dhanbad 826 004, India
}

In the present study, ICP-AES and ICP-MS techniques were used to analyse and validate the content of heavy and trace elements in yellow gypsum samples produced by a chemical process from a solid waste generated at an integrated steel plant. The present study tries to demonstrate that the content of heavy metals like lead, mercury and arsenic in yellow gypsum is less than the toxicity characteristic leaching procedure (TCLP) norms set for a comparable industrial by-product phospho-gypsum. This study also concludes that yellow gypsum contains some elements (copper, boron, etc.) in traces, apart from heavy metals which are beneficial to plants as micronutrients.

Keywords: Heavy metals, ICP-MS, ICP-AES, trace elements, yellow gypsum.

QUANTIFICATION of hazardous, heavy and trace elements in products, particularly produced from industrial wastes is very important for their possible applications in various sectors especially in agriculture. Efforts are being made worldwide by scientists for economic utilization of steel plant wastes. One such effort is the production of high purity iron and $\mathrm{CaO}$-based sorbent using acetic acid by Tian et al. ${ }^{1}$ and secondly production of yellow gypsum and gypsum by Ashrit et al..$^{2,3}$.

Yellow gypsum produced from the Ling-Donawitz (LD) slag fines has very good plant nutrient value in terms of calcium, iron, phosphorus, magnesium and silicon, apart from various other trace elements beneficial for plants like boron, copper, manganese, etc. Environment protection agency (EPA), USA has also studied the quantity of contaminants mainly heavy metals and nonnutrient metals present in various fertilizers as a part of information gathering initiative $e^{4}$. Such studies are essential as these contaminants enter the food chain through plants and vegetables. To quantify the heavy and trace elements present in yellow gypsum, sample preparation is an important step of the analysis. Lithium metaborate fusion dissolution method and open acid digestion with different acid combinations followed by inductively coupled plasma-mass spectroscopy (ICP-MS) analysis were discussed by Roy et al. ${ }^{5}$. Similarly, Cremer and Schlocker $^{6}$ had discussed about lithium borate fusion

*For correspondence. (e-mail: shrenivas@tatasteel.com) 
technique for dissolution of zircon and fluocerite. Lithium metaborate dissolution for rocks, minerals and ores was originally proposed by Ingamells ${ }^{7}$, and along with $\mathrm{Suhr}^{8}$ later suggested its use for analysis via flame atomic absorption spectrophotometry technique. The major disadvantage of this type of dissolution is that the silica concentration should not exceed 150 parts per million, otherwise it will result in the polymerization and precipitation of silica. On the other hand if the solution is too dilute, low levels of constituents cannot be determined accurately as described by Shapiro and Brannock ${ }^{9}$. Thus, the digestion of silicate samples often remain unfinished $^{10,11}$ and affects the accuracy and precision of elements to be estimated. The most commonly used methods of sample preparation either employ dissolution by fusion or acid digestion involving mixtures of acids such as $\mathrm{HF}+\mathrm{HNO}_{3}, \mathrm{HNO}_{3}+\mathrm{HCl}, \mathrm{HClO}_{4}+\mathrm{HF}$, etc.

Inductively coupled plasma atomic emission spectrometry (ICP-AES) is accepted widely and extensively used for estimation of minor and trace elements present in the ores, minerals and other related samples ${ }^{12,13}$. ICP-MS has been used as an analytical technique for analysing the trace elements in geological samples ${ }^{14,15}$, however, we have used it now for the analysis of synthetic gypsum produced from chemical treatment of steel plant waste.

ICP-AES is also a well established technique in the field of estimation of trace which was done by neutron activation analysis (NAA) since few decades, and estimation of major elements was by X-ray fluorescence spectrometer (XRF). However, ICP-AES is gaining momentum and gradually becoming more popular, as major and trace elements can be determined together using ICP-MS ${ }^{16,17}$. ICP-MS is recognized as an effective technique for the determination of trace elements including rare earth elements in ceramics, etc. ${ }^{18}$. Thus both the methods have been well established to be the dominant methods for trace level detection of elements.

It is now apparent that combination of ICP-AES and ICP-MS techniques has huge potential for the determination of large chunks of trace elements and rare earth elements in various minerals, ores and geological samples. A major difficulty to overcome in the process of estimation of trace elements is the sample dissolution step, where the use of appropriate alkali or acid to achieve complete dissolution is critical.

There are several methods of sample dissolution techniques used by various researchers ${ }^{19-21}$; these include partial digestion (acid leaching) and fusion with alkali fluxes including certain methods developed for specific applications (mainly for determination of one or few elements). Alkaline fusion with $\mathrm{NaOH}+\mathrm{Na}_{2} \mathrm{O}_{2}$ was also followed for determination of rare earth and other trace elements by ICP-MS ${ }^{22}$. Sodium carbonate fusion is a common procedure used mainly for silicates (clays, minerals, glass, rocks, slags, etc.) refractory oxides, insoluble phosphates and sulphates ${ }^{23}$. Several acids are com- monly used in wet ashing procedure. The dissolution process in this method is simply a replacement of hydrogen by metal ${ }^{24}$. The main objective of the present work was to explore the potential of yellow gypsum as a synthetic soil conditioner produced from wastes generated in steel making with the help of ICP-AES and ICP-MS techniques. Also, the present study endeavours to demonstrate that the content of heavy metals like lead, mercury and arsenic in yellow gypsum is less than the toxicity characteristic leaching procedure (TCLP) norms set for a similar industrial by-product phospho-gypsum.

In the present study, a simple technique of sample decomposition was selected as compared to the one suggested by Yokoyama et $a .^{25}$ and Sharma et $a .^{26}$, wherein a combination of perchloric acid and HF was used. We have instead used aqua-regia as a reagent for sample dissolution, wherein $1 \mathrm{~g}$ of accurately weighed yellow gypsum sample was taken into a $250 \mathrm{ml}$ teflon beaker and $40 \mathrm{ml}$ of aqua-regia was added. The beaker was heated on a digital hot plate under a fume hood at controlled temperature for a time period so that the volume of the solution reduced to half, i.e. $20 \mathrm{ml}$. The aqua-regia solution was prepared by using concentrated

Table 1. Optimized inductively coupled plasma atomic emission spectrometry (ICP-AES) instrument operating parameters

\begin{tabular}{lc}
\hline Instrument parameters & Values \\
\hline Model & Spectro, Arcos, Germany \\
Plasma power & $1400 \mathrm{~W}$ \\
Pump speed & $30 \mathrm{rpm}$ \\
Coolant flow & $141 / \mathrm{min}$ \\
Auxiliary flow & $1.01 / \mathrm{min}$ \\
Acquisition time & $45 \mathrm{sec}$ \\
Number of replicates & 3 \\
Curve type & Linear \\
\hline
\end{tabular}

Table 2. Optimized ICP-MS instrument operating parameters

\begin{tabular}{lc}
\hline $\begin{array}{l}\text { Instrument operating } \\
\text { parameters }\end{array}$ & Values \\
\hline Instrument & \\
Model & Perkin-Elmer, DRC-e \\
RF Power & $1350 \mathrm{~W}$ \\
Plasma gas flow & $15 \mathrm{l} / \mathrm{min}$ \\
Auxiliary gas flow & $1.21 / \mathrm{min}$ \\
Nebuliser gas flow & $0.881 / \mathrm{min}$ \\
& \\
Acquisition & \\
Scanning mode & Peak hopping \\
AMU & $50 \mathrm{~ms}$ \\
Integration mode/time & Cps/1000 ms \\
Detector dead time & $70 \mathrm{~ns}$ \\
Acquisition time & $20 \mathrm{sec}$ \\
Number of replicates & 3 \\
Curve type & Linear \\
\hline
\end{tabular}


Table 3. Comparing heavy metal concentrations with TCLP norms for phospho-gypsum

\begin{tabular}{lccc}
\hline $\begin{array}{l}\text { Trace and heavy metals } \\
\text { in yellow gypsum }\end{array}$ & $\begin{array}{l}\text { Values } \\
(\mathrm{mg} / \mathrm{l})\end{array}$ & $\begin{array}{c}\text { TCLP test norms for phospho-gypsum } \\
\text { (not to exceed mg/l) }\end{array}$ & $\begin{array}{c}\text { Meeting the } \\
\text { norms (yes/no) }\end{array}$ \\
\hline Lead & 1.7 & 5 & Yes \\
Arsenic & 0.08 & 5 & Yes \\
Mercury & 0.06 & 0.2 & Yes \\
\hline
\end{tabular}

Table 4. Trace elements' concentration in yellow gypsum by ICP-AES and ICP-MS instruments

\begin{tabular}{lcccccc}
\hline & & \multicolumn{3}{c}{ Values $(\mu \mathrm{g} / \mathrm{m})$} & & \\
\cline { 3 - 5 } Parameters & Method & Repeat 1 & Repeat 2 & Repeat 3 & Average $(\mu \mathrm{g} / \mathrm{g})$ & Standard deviation \\
\hline $\mathrm{V}$ & ICP-AES & 43.67 & 41.01 & 40.85 & 41.84 & 1.58 \\
$\mathrm{Sr}$ & ICP-AES & 69.55 & 65.79 & 65.91 & 67.08 & 2.14 \\
$\mathrm{Sn}$ & ICP-AES & 42.23 & 40.63 & 40.37 & 41.08 & 1.01 \\
$\mathrm{~B}$ & ICP-AES & 50.35 & 47.30 & 47.46 & 48.37 & 1.72 \\
$\mathrm{Cr}$ & ICP-AES & 115.8 & 117.4 & 118.5 & 117.2 & 0.36 \\
$\mathrm{Mo}$ & ICP-MS & 0.31 & 0.32 & 0.28 & 0.30 & 0.38 \\
$\mathrm{Ba}$ & ICP-MS & 11.56 & 10.94 & 10.87 & 11.12 & 0.04 \\
$\mathrm{Ni}$ & ICP-MS & 2.90 & 2.83 & 2.83 & 2.85 & 0.03 \\
$\mathrm{Co}$ & ICP-MS & 1.28 & 1.25 & 1.21 & 1.25 & 0.02 \\
$\mathrm{Cd}$ & ICP-MS & 1.31 & 1.29 & 1.28 & 1.29 & 0.17 \\
$\mathrm{Cu}$ & ICP-MS & 4.61 & 4.31 & 4.32 & 4.41 & \\
\hline
\end{tabular}

supra pure $\mathrm{HCl}$ and $\mathrm{HNO}_{3}$. Water used in the sample preparation process was deionized water with a resistivity of $>18.3 \mathrm{M} \Omega \mathrm{cm}^{-1}$ using a Milli-Q system. The reduced volume of solution was cooled, filtered and transferred quantitatively to a $100 \mathrm{ml}$ volumetric flask.

The analytical characteristics of both the techniques, i.e. ICP-AES and ICP-MS setups used in the present work are described in detail, based on the study by Hein et $a .^{27}$. ICP-MS has been successfully applied for rapid and precise measurement of wide range of elements ${ }^{28}$. However, heavy metal contents still cannot be easily measured due to difficulties in sample preparation, sensitivity limits of instrument and complicated matrix effects. The recent advances in ICP-MS technology like micro sample introduction methods, etc. have significantly improved the performance in quantification of trace elements.

ICP-AES determinations were carried out using Spectro ARCOS, spectrometer (Germany), with a working plasma power of $1400 \mathrm{~W}$ and other operating parameters as mentioned in Table 1.

The calibration of the instrument was performed using a blank prepared by using the acids in the same proportion, as used for sample preparation. Four standard multielement solutions were prepared by diluting a concentrated multi-element standard solution containing all the elements to be determined by ICP-AES. For preparing the multi-element solution, National Institute of Standards and Technology (NIST) traceable multi-element E Merck standard solutions of $1000 \mathrm{ppm}$ concentration were used (E Merck CRM 1V).
The ICP-MS determinations were carried out using Perkin Elmer DRC-e Instrument whose operating parameters are provided in Table 2.

Adoption of a suitable sample dissolution method is very important for the assessment of heavy metals and other elements present in traces. Several researches have examined dissolution process by using aqua-regia and total dissolution by using hydrofluoric acid to establish total concentrations ${ }^{29}$. Other dissolution techniques like the application of HF for digestion with secondary acids mainly $\mathrm{HNO}_{3}, \mathrm{H}_{2} \mathrm{SO}_{4}$ or $\mathrm{HClO}_{4}$ were also studied ${ }^{18}$. Dissolution by alkali fusion involving either sodium carbonate or sodium hydroxide, where the determination of sodium is not required and finally the use of lithium metaborate as a flux useful for the determination of all elements including silicon in silicate dominant samples or many minerals containing silicon. The main drawback of these alkali fusion techniques is high flux to sample ratios like $5: 2$ and $7: 2$ at which the total dissolved solids in the resultant solution will be high and may end up with the choking of nebulizer. The method of dissolution described above has no such drawbacks and can produce recoveries more than $95 \%$ for certified reference materials (CRMs) used for validation of the method.

Table 3 provides the comparison of heavy and hazardous elements concentration in the yellow gypsum tested by ICP-MS, with the TCLP norms set for phosphogypsum for application in agriculture as a soil conditioner. As the data (Table 3) indicates, yellow gypsum meets the norms set by TCLP tests and the concentration of heavy and hazardous elements in the yellow gypsum are 
RESEARCH COMMUNICATIONS

Table 5. Validation of results using multi-element standard solution using ICP-AES and ICP-MS instruments

\begin{tabular}{|c|c|c|c|c|c|}
\hline Merck CRM IV & Method & $\begin{array}{c}\text { Certified values } \\
\text { (undiluted stock } \\
\text { solution; mg/l) }\end{array}$ & $\begin{array}{c}\text { Working values } \\
\text { (working solutions; } \mathrm{mg} / \mathrm{l} \text { ) }\end{array}$ & $\begin{array}{c}\text { Observed } \\
\text { values }(\mathrm{mg} / \mathrm{l})\end{array}$ & Recovery (\%) \\
\hline $\mathrm{Ba}$ & ICP-AES & 1000 & 100 & 99 & 99 \\
\hline $\mathrm{Ni}$ & ICP-AES & 1006 & 100 & 102 & 102 \\
\hline Co & ICP-AES & 1005 & 100 & 103 & 103 \\
\hline $\mathrm{Sr}$ & ICP-AES & 1004 & 100 & 97 & 97 \\
\hline B & ICP-AES & 1000 & 100 & 99 & 99 \\
\hline $\mathrm{Cr}$ & ICP-AES & 1004 & 100 & 103 & 103 \\
\hline $\mathrm{Ba}$ & ICP-MS & 1000 & 100 & 95 & 95 \\
\hline $\mathrm{Ni}$ & ICP-MS & 1006 & 100 & 97 & 97 \\
\hline $\mathrm{Sr}$ & ICP-MS & 1004 & 100 & 97 & 97 \\
\hline B & ICP-MS & 1000 & 100 & 98 & 98 \\
\hline $\mathrm{Cr}$ & ICP-MS & 1004 & 100 & 101 & 101 \\
\hline
\end{tabular}

Table 6. Validation of results by certified reference materials using ICP-AES and ICP-MS instruments

\begin{tabular}{|c|c|c|c|c|}
\hline & Method & Certified values $(\mu \mathrm{g} / \mathrm{g})$ & Observed values $(\mu \mathrm{g} / \mathrm{g})$ & Recovery (\%) \\
\hline \multicolumn{5}{|c|}{ CRM no. SARM-5 } \\
\hline $\mathrm{Ni}$ & ICP-AES & 555 & 545 & 98 \\
\hline $\mathrm{V}$ & ICP-AES & 230 & 222 & 97 \\
\hline \multicolumn{5}{|c|}{ CRM No. 683-1 } \\
\hline $\mathrm{Cr}$ & ICP-AES & 180 & 190 & 106 \\
\hline \multicolumn{5}{|c|}{ CRM No 681-1 } \\
\hline $\mathrm{Pb}^{*}$ & ICP-MS & 72 & 69 & 96 \\
\hline $\mathrm{Co}^{*}$ & ICP-MS & 80 & 85 & 106 \\
\hline As* & ICP-MS & 139 & 135 & 97 \\
\hline
\end{tabular}

*Reference values.

much lower compared to the TCLP values of leachate of phospho-gypsum ${ }^{30,31}$.

Other trace elements present in the phospho-gypsum are provided in Table 4 and the data shows that the values for each individual element are much below the norms set by the government/regulatory authorities. Some elements like boron, vanadium, tin, copper, etc. are well recognized micro-nutrients for plants.

The results obtained by ICP-AES and ICP-MS methods were validated by using the CRM's and synthetic standard solutions traceable to NIST (E. Merck CRM IV), prepared under similar conditions along with the yellow gypsum sample.

E. Merck CRM IV was used for validation of elements concentration (Table 5), by adding the known quantity of major matrix elements present in the yellow gypsum to the synthetic standard and then recovery of the minor elements were calculated to establish the correctness of findings. E. Merck CRM IV solution was analysed both in ICP-AES and ICP-MS instruments. In a similar way, Bureau of Analysed Samples (BAS) Ltd standards like SARM-5 and 683-1 containing the elements of our inter- est were prepared and the solution matrix was matched to yellow gypsum using the analytical grade calcium sulphate and the recovery was calculated as presented in Table 6 (analysed in ICP-AES and ICP-MS instruments).

Due care was taken in preparing the calibration curve covering the analysis range and linearity. The line of best fit with $Y$ intercept close to zero and correlation coefficient of more than 0.9999 was used. Validation parameters of other methods like repeatability and ruggedness and intermediate precision were also carried out by analysing the sample several times and on different days.

It is evident from the present study that yellow gypsum is suitable as a soil conditioner as it contains better nutritional value in terms of sulphur, calcium, iron, phosphorus and silica with reference to mineral gypsum. Thus, yellow gypsum is important in the conservation of natural resources which helps in the effective and economical utilization of industrial solid wastes. It also contains traces of micro-nutrients like copper, boron, nickel molybdenum, etc. which are essential part of plant nutrition system. Silica, another useful constituent in yellow 
gypsum, helps in plant growth and provides strength to stem and yield according to recent studies. Content of heavy metals and other hazardous metals is quite below the limit set by TCLP for the product of similar nature such as phospho-gypsum. Major advantage of yellow gypsum is its composition which is full of micro nutrients and hence, is fit for use as a soil conditioner.

1. Tian, S., Jiang, J., Yan, F., Li, K., Chen, X. and Manovic, V., Highly efficient $\mathrm{CO}_{2}$ capture with simultaneous iron and $\mathrm{CaO}$ recycling for the iron and steel industry. Green Chem., 2016, 18, 4022-4031.

2. Ashrit, S., Banerjee, P. K., Chatti, R. V., Venugopal, R. and Udayabhanu, G. N., Characterization of yellow gypsum synthesized from LD slag fines generated at waste recycling plant of a steel plant. Curr. Sci., 2015, 109, 727-732.

3. Ashrit, S., Banerjee, P. K., Chatti, R. V., Venugopal, R. and Udayabhanu, G. N., Characterization of gypsum synthesized from LD slag fines generated at waste recycling plant of a steel plant. New J. Chem., 2015, 39, 4128-4134.

4. United States Environmental Protection Agency. Background report on fertilizer use, contaminants and regulations, EPA 747-R98-003, 1999

5. Roy, P., Balaram, V., Bhattacharaya, A., Nasipuri, P. and Satyanarayanan, M., Estimation of Ti, Zr, Nb, Hf, Ta, Th and $\mathrm{U}$ in beach placers and ferro diorites by inductively coupled plasmamass spectroscopy using lithium metaborate fusion digestion technique. Curr. Sci., 2007, 93, 1122-1126.

6. Cremer, M. and Schlocker, J., Lithium borate decomposition of rocks, minerals, and ores. Am. Mineral., 1976, 61, 318-321.

7. Ingamells, C. O., Rapid chemical analysis of silicate rocks. Talanta, 1964, 11, 665-666.

8. Suhr, N. H. and Ingamells, C. O., Solution technique for analysis of silicates. Anal. Chem., 1966, 38, 730-734.

9. Shapiro, L. and Brannock, W. W., Rapid Analysis of Silicates, Carbonates and Phosphate Rocks, US Geological Survey Bulletin, 114A, United States Government Printing Office, Washington, 1962, revised edn.

10. Totland, M., Jarvis, I. and Jarvis, K. E., An assessment of dissolution techniques for the analysis of geological samples by plasma spectrometry. Chem. Geol., 1992, 95, 35-62.

11. Totland, M., Jarvis, I. and Jarvis, K. E., Microwave digestion and alkali fusion procedures for the determination of the platinumgroup elements and gold in geological materials by ICP-MS. Chem. Geol., 1995, 124, 21-36.

12. Walsh, J. N. and Howie, R. A., An evaluation of the performance of an inductively coupled plasma source spectrometer for the determination of the major and trace constituents of silicate rocks and minerals miner. Mineral. Mag., 1980, 43, 967-974.

13. Bakhtar, D., Bradford, G. R. and Jund, L., Dissolution of soils and geological materials for simultaneous elemental analysis by inductively coupled plasma optical emission spectrometry and atomic absorption spectrometry. Analyst, 1989, 114, 901-909.

14. Jarvis, K. E., Determination of rare earth elements in geological samples by inductively coupled plasma mass spectrometry. J. Anal. Atom. Spectrom., 1989, 4, 563-570.

15. Bettinelli, M., Baffi, C., Beone, G. M. and Spezia, S., Soils and sediments analysis by spectroscopic techniques part II: determination of trace elements by ICP-MS. Atom. Spectrosc., 2000, 21, 60-70.

16. Paama, L., Peramaki, P., Lajunen, H. J. and Piiri, L., Spectrochemical analysis of archaeological terra-cotta samples and clay minerals using ICP-AES. Atom. Spectrosc., 1995, 16, $248-250$.
17. Bruno, P., Caselli, M., Curri, M. L., Genga, A., Striccoli, R. and Traini, A., Chemical characterization of ancient pottery from south of Italy by inductively coupled plasma atomic emission spectroscopy (ICP-AES): statistical multivariate analysis of data. Anal. Chim. Acta, 2000, 410, 193-202.

18. Tsolakidou, A., Garrigós, J. B. I. and kilikoglou, V., Assessment of dissolution techniques for the analysis of ceramic samples by plasma spectrometry. Anal. Chim. Acta, 2002, 474, 177-188.

19. Bock, R., A handbook of decomposition methods in analytical chemistry (translated and revised by Marr, I. L.), International Textbook Co, Glasgow, UK, 1979, p. 444.

20. Borman, S. A., Microwave dissolution. Anal. Chem., 1988, 60, 715a-716a.

21. Sulcek, Z. and Povondra, P., Methods of decomposition in inorganic analysis. In Methods of Decomposition in Inorganic Analysis, CRC Press, 1989, p. 325.

22. Bayon, G., Barrat, J. A., Etoubleau, J., Benoit, M., Bollinger, C. and Révillon, S., Determination of rare earth elements Sc, Y, Zr, $\mathrm{Ba}, \mathrm{Hf}$ and $\mathrm{Th}$ in geological samples by ICP-MS after Tm addition and alkaline fusion. Geostand. Geoanal. Res., 2009, 33, 51-62.

23. Bogen, D. C., Decomposition and Dissolution of Samples: Inorganic. In Treatise on Analytical Chemistry Part 1, Wiley-Inter Science, New York, 1978, pp. 1-22.

24. Dean, J., Lange's Analytical Chemistry Handbook, McGraw-Hill, New York, 1995.

25. Yokoyama, T. A., Makishima, V. and Nakamura, E., Evaluation of the coprecipitation of incompatible trace elements with fluoride during silicate rock dissolution by acid digestion. Chem. Geol., 1999, 157, 175-187.

26. Sharma, A. L., Alard, O., Elhlou, S. and Pearson, N. J., Evaluation of perchloric versus nitric acid digestion for precise determination of trace and ultra-trace elements by ICP-MS. In Goldschmidt 2000: An International Conference for Geochemistry, Oxford, UK, 2000, p. 914.

27. Hein, A. et al., Standardisation of elemental analytical techniques applied to provenance studies of archaeological ceramics - an inter laboratory calibration study. Analyst, 2002, 127, 542-553.

28. Eggins, S. M. et al., A simple method for the precise determination of 40 trace elements in geological samples by ICP-MS using enriched isotope internal standardization. Chem. Geol., 1997, 134, 311-326.

29. Marr, I. L., Kluge, P., Main, L., Margerin, V. and Lescop, C., Digests or extracts? - Some interesting but conflicting results for three widely differing polluted sediment samples. Microchim. Acta, 1995, 119, 219-232.

30. CPCB Document-PROBES/124/2008-2009, Protocol for performance evaluation and monitoring of the common hazardous waste treatment storage and disposal facilities including common hazardous waste incinerators, Central Pollution Control Board, New Delhi, 24 May 2010.

31. CPCB, Guidelines for Management and Handling of Phosphogypsum Generated from Phosphoric Acid Plants (Final Draft), Central Pollution Control Board, New Delhi, 2012.

ACKNOWLEDGEMENTS. We thank Dr Sanjay Chandra, Chief of R\&D, Tata Steel for giving an opportunity to carry out the study, support and permission to present the findings. The support and services provided by staff of Chemical Laboratory, Scientific Services Division are also duly acknowledged.

Received 10 June 2019; revised accepted 18 September 2019

doi: $10.18520 / \mathrm{cs} / \mathrm{v} 118 / \mathrm{i} 1 / 118-122$ 